\title{
Social Justice through Humanism: M.N. Roy and Erich Fromm
}

\author{
Dr. Naushaba Anjum
}

\begin{abstract}
The word 'humanism' came into general use in 19th century however, the concept is as old as philosophy itself. In order to explain the concept of humanism it is important to state in brief what exactly is meant by humanism. All humanists are self-professedly committed to man. They stand for the actualization of human potentialities. They wish to contribute to human happiness, social justice, democracy and peaceful world-order. All of them believe that authoritarianism and totalitarianism is dehumanizing, all of them are sympathetic to human suffering and are committed to the unity of mankind.
\end{abstract}

Index Terms - Actualization, Democracy, Humanism, Peace

\section{INTRODUCTION}

The philosophy of humanism has had to pass through a process of development and change. But, its main concept that man is supremely placed in the cosmic scheme of things and he must be the center of attention in all walks of life has remained constant throughout. We can say that humanism recognizes the value and dignity of man and makes him "the measure of all things" as Protagorous said, so, in this sense, humanism can be said to be quite simply a study of man.

Humanist philosophy with a secular and scientific orientation is against all types of illusions related to man and his surroundings in this universe. This type of humanism involves a scientific view of nature of man. Any theistic interpretation of the world and any ecclesiastical drama about the divine beginning and end is rejected because it is scientifically unproved, logically meaningless and empirically unverified.

Although humanism is rooted in the thought of ancient Greeks and Romans, its focus on the study of humanity formed the intellectual core of cultural reawakening called the Renaissance. That humanistic attitude towards the life has continued till date. there are some outstanding $20^{\text {th }}$ century humanists like J.P. Sartre, Gilbert Murray, Bertrand Russell, S. Radhakrishnan, Rabindranath Tagore, Erich Fromm and M.N. Roy who in their multiple socio-cultural and historical contents kept the flag of humanism, flying although all of them did not necessarily agree on all the characterizing features of modern-day Humanism Presently, we shall attempt a brief note on the radical humanism of M.N. Roy in comparison to the humanistic stand point of Erich Fromm.

M.N. Roy (1887-1957) attempts to give a scientific exposition of philosophy. He tries of find how far philosophy can help us solve the socio-political problems of our times. Roy tries of bring out the demarcation between philosophy and religion in the thought. According to him, no philosophical advancement is possible unless we get rid of orthodox religious ideas and theological dogmas. He writes:

Dr. Nauahsaba Anjum, Department of Philosophy, A.M.U. Aligarh/ (UP) India/ 9410890140
"Philosophy is contemplation, study and knowledge of nature. its function is to know things as they are and to find common origin of the diverse phenomena of nature, in nature itself. Roy started as a naturalist thinker and activist but soon gravitated towards Marxian thought. He was influenced by Marx but was not a blind follower of Marxism. He started with an attempt at fundamental revision of Marxism and finally abandoned it in favour of his own philosophy of radical Humanism. Roy's intellectual career had two distinct stages; first when be became a Marxist in 1916 and second, when he replaced it by his radical humanism in 1946, it was a sudden jump from Marxism to radical Humanism.

Roy starts his humanism under the title 'New Humanism a Manifesto.' It elaborates the inadequacy of present ideologies and degeneration of communist theories and practice. It represents the philosophy of new humanism which is further designated as Radical Humanism.

Roy's humanism is known as 'Scientific Humanism', 'Radical Humanism 'and 'Integral Humanism.' It is "new", because it is reinforced by scientific knowledge and also by social experience received by modern civilization, it is 'Scientific', because it conceives human reality as a byproduct of natural evolution. And, it is also "Radical" because it goes to the root of the problem of the human being.

Roy's humanism is basically on scientific knowledge of man and his nature. This humanism can explain man as man. According to Roy, previously man did not believe in his own creative abilities. He was made a slave of the supernatural powers. Afterwards, he regained faith in himself. Thereafter, man created society, state, institutions, values, etc, for his own welfare. Man has the power to change for his welfare and advancement. Roy's humanism revolves around man.

Roy's Radical humanism is based on a set of principles. These principles have relevance to all branches of human life and social existence. His philosophy of that humanism is not only an abstract philosophy or merely a social or political or economic philosophy." It is rather a kind of philosophy which can inspire mankind to take things in its own hand. It shapes the social world according to reason and human needs." 2

Roy claims that the humanist thinkers of 18 th century were not able to trace the relationship between man and nature. Now Roy's Humanism has removed that problem through modern science.

The conclusions of Roy's humanism are derived by adopting the approach of science to the understanding of man. It also tries to understand man's relation to man and his place in the world. According to Roy "modern science had acquired a good deal of knowledge about man, It is therefore possible to dispense with many assumptions and prejudices. It also helps us to have a rational, scientific understanding of human nature." 
Radical humanism, according to Roy, rejects the affairs of the world as determined by any supernatural power. It believes that the nature of man is determined not by divine will but by natural forces. Radical humanism also insists that man is an end in himself, It can not be required to merge into something supernatural of superempirical. It rejects the existence of any supernatural powers. It traces all the mental attributes of man; his will, reason and emotions, to the millions of years of physico-biological evolution.

In introduction of Erich Fromrn's humanism. Erich Fromm was one of those who worked and wrote for a better or more dignified life for all humanity. Like Roy, he had firm faith in human potentiality for self realization. He too was an athiest who regarded belief in the personal, creator God as inadmissible, Fromm believes that today everything is within man's grasp. For Fromm, It is difficult to define the limits or boundaries of human life. Progress, prosperity and physical comfort are the new goals pursued by man. But apart form this generally accepted trend' Formm talks passionately about the values of freedom, justice and love, he has made greater claims for the power of human spirit than any other humanist of his times. He is a thinker who has tried to teach man the way to freedom without rationalism, self-love without selfishness and religion without theology. The most important problem for Fromm was in what specific ways an individual could adjust himself to the world. Being a socialist humanist his greatest inspiration was of course Karl Marx whom he described as one of the greatest humanists of past century. A man, Marx said, can not be regarded as independent unless he is his own master. And, he has the power of inner productivity or potentiality not mortgaged to anyone.

Fromm's concept of sane man is rooted in the humanistic concept of independent, active and productive man. The independence of action lies in the act of self-creation. Self realization is man's innermost necessity. In the words of Marx "A being only considers himself independent when he stands on his own feet, and he only stands in his own feet when he owes his existence to himself. A man who lives by the grace of another regards himself as a dependent being."

Formm thinks that we can create the new world with the help of reason and love for life. His humanism is known as Socialist humanism. Fromm says man finds satisfaction only through society. Man's survival depends upon his finding satisfying relation with other. This basic need is behind the entire human relation that man seeks through what we call 'love' in broadest sense.

This aspect of humanism on which Formm focuses is what makes it social at another level. For Formm, human egoism, man's emphasis of personal interest and satisfaction must have a social perspective such that individual needs coalesce into the collective needs.

Fromm says', Marxim is humanism and its aim is the full unfolding of man's potentialities; not man as deduced from his idea or his consciousness, hut man with his physical and psychic properties; the real man who does not live in vacuum but in a social context, the man who has to produce in order to live. ${ }^{5}$

Man is always an end in himself and can never be a means to some other end. He has ability to perfect himself in the process of history.

According to Fromm, there are four main principles of humanism.

1. belief in the unity of human race.

\section{2. emphasis on man's dignity.}

3.emphasis on man's capacity to develop and perfect himself 4. emphasis on reason, objectivity and peace.

In conclusion it is seen that Roy and Fromm in spite of having borrowed their philosophies from Marxian and anti-Marxian thought, are rightly considered as important and influential humanists in a proper and academic sense.

Both of them hope for the creation of sane and sensible individual to replace the modern, mechanical and materialistic man of west. He must come out of the dark and ugly face of humanity of today. Man must break free from cult of violence hatred and jealousy, which fills human personality at large. All is not lost. These philosophical perspectives contain humanistic practical and pragmatic elements that have undoubtedly greater relevance to the modern world-situation.

\section{REFERENCES}

[1] M.N. Roy; 'Materialism -An outline of the history of scientific Thought' Ajanta publication, Delhi, p. 1

[2] M.N. Roy; 'Politics, Power and Parties' op. cit.p.140

[3] lbid, p. 133

[4] Karl Marx; 'Economic and philosophical' Manuscripts of 1844, p. 99

[5] Eric Fromm, On Disobedience, p. 47

[6] Erich Fromm; Escape from Freedom, Holt Rinchart and Winston, Inc, New York, 1947.

[7] Erich Formm, Marx's Concept of Man, Frederick Ungar publishing Co. New York, 1963.

[8] Erich Formm, Man for Himself; Rutledge and Kegan Paul Ltd., Londan, 1947

[9] Erich Fromm, The Sane Society; Rouledge and Kegan Paul Ltd., London, 1955

[10] M.N. Roy; 'A New Approach to Communal Problem' V.B. Larnik, Bombay, 1947

[11] M.N. Roy; 'New Humanism-A Manifesto' Renaissance Publishers, Calcutta, 1947

[12] M.N. Roy; 'Radical Humanism' Eastern Economist, New Delhi, 1992

Dr. Naushaba Anjum is Assistant Professor in the Department of Philosophy, Aligarh Muslim University, Aligarh. Dr. Anjum ranked first in M.A. and obtained University Gold Medal. She was also recipient of I.C.P.R. Fellowship. Dr. Anjum submitted her Ph.D. thesis in 2004 and was appointed as Lecturer in the Department of Philosophy in the same year. Dr. Anjum has teaching and research experience of more than 15 years. Her teaching interests include Logic and Scientific Method, Western Philosophy and Existentialism. 